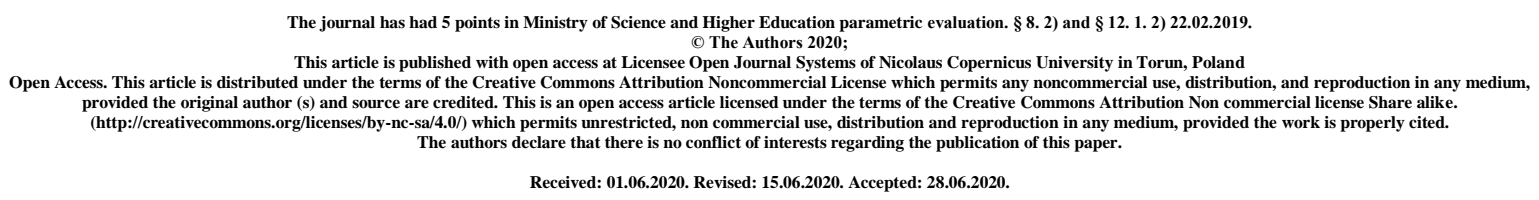

\title{
Principles of Drawing up Tax Consulting Outsourcing
} Agreements

\section{Izabela Bagińska}

Częstochowa University of Technology, Częstochowa, Poland

\begin{abstract}
The basic objective of the article is to indicate the principles of drawing up tax consulting outsourcing agreements, to analyze the scope of such agreements, and identify the benefits and threats resulting from the correct construction thereof. The first part includes a review of the literature in the scope of outsourcing. Then, the results of empirical research are presented. Anonymous studies were conducted among medium and small enterprises using questionnaires.
\end{abstract}

Key words: outsourcing, civil law agreement 


\section{Introduction}

For some time, outsourcing has been an attractive solution for entrepreneurs. It allows reducing the costs of business activity. Additionally, it allows to improve the quality of services provided and to concentrate on the core activity, which provides access to expertise and new technologies ${ }^{1}$. Those activities directly improve the competitiveness of an enterprise. Apart from numerous advantages, outsourcing may also pose certain risks. The most frequent cause of failure is when outsourcing cooperation is started with the wrong service provider. As a result, the company may slow down or even go bankrupt.

\section{Origin and Idea of Outsourcing}

The development of outsourcing is affected by such phenomena as:

- globalization,

- reengineering,

- lean management.

The phenomenon of globalization is highly correlated to transfers of production and services which, in turn, gave rise to outsourcing and offshoring. Developing globalization affects both people and the functioning of enterprises. Globalization affects primarily the economy and market. Its task is to eliminate barriers in international economic exchange. This significantly streamlines technological progress. Globalization is changing the structure of the needs of the society. Internet development, and the resulting unlimited capacity for communication have resulted in a situation that you can see the same or similar products in any place and at any time.

Globalization has increased competitive pressure. The enterprises that want to obtain a competitive advantage in the market must quickly react to the changes taking place in their environments. The decision to replace the older management methods with more innovative ones can often prove of strategic importance for enterprises. The methods that allow enterprises to achieve the benefits resulting from the reduction in cost, time, and service, are reengineering (Business Process Reengineering BPR) and lean management.

The precursors of reengineering were J. Champy and M. Hammer. That management method assumes a complete transformation of processes within an enterprise resulting in a radical improvement ${ }^{2}$. Reengineering causes significant changes in the enterprise. The workplace, employee attitudes, remuneration system, and role of superiors, are changing. So is the organizational structure - from a hierarchical to a flatter one.

Lean management is a management concept consisting of increasing the added value of activities. The method develops a new work culture within the enterprise, in which everyone aims to reduce costs, improve quality, and shorten the delivery cycle. The objective of the activities is to meet the changing expectations of the buyers. Lean management is mainly used in the process of enterprise restructuring.

Both reengineering and lean management assume concentration on key competences. The common property of both concepts is outsourcing cooperation.

\footnotetext{
${ }^{1}$ Belcourt, M. (2006). Outsourcing-The benefits and the risks. Human resource management review, 16(2), 269.

2 J. Champy, M. Hammer, Reengineering the Corporation: a manifesto for business revolution, Harper Business, New York 1993, p. 46.
} 
At first, outsourcing was understood as a cost-reducing method. It applied to such activities as cleaning or security services. Over time, enterprises started to outsource more and more activities. Nowadays, outsourcing is perceived as a long-term strategy that allows obtaining a competitive advantage ${ }^{3}$ (see fig. No. 1).

The 1960s and 1970s saw the development of the make or buy concept which was associated with the dilemma whether you should do something on your own or quite the contrary - order a third party to do it. Thus outsourcing was born, which today is used in almost every area of activity of an enterprise ${ }^{4}$. The English word outsourcing means using external sources to support business processes. In order to obtain an advantage in the market, enterprises concentrate on their core activities and outsource certain functions to specialized third parties.

\section{Figure 1.}

\section{Evolution of Outsourcing}

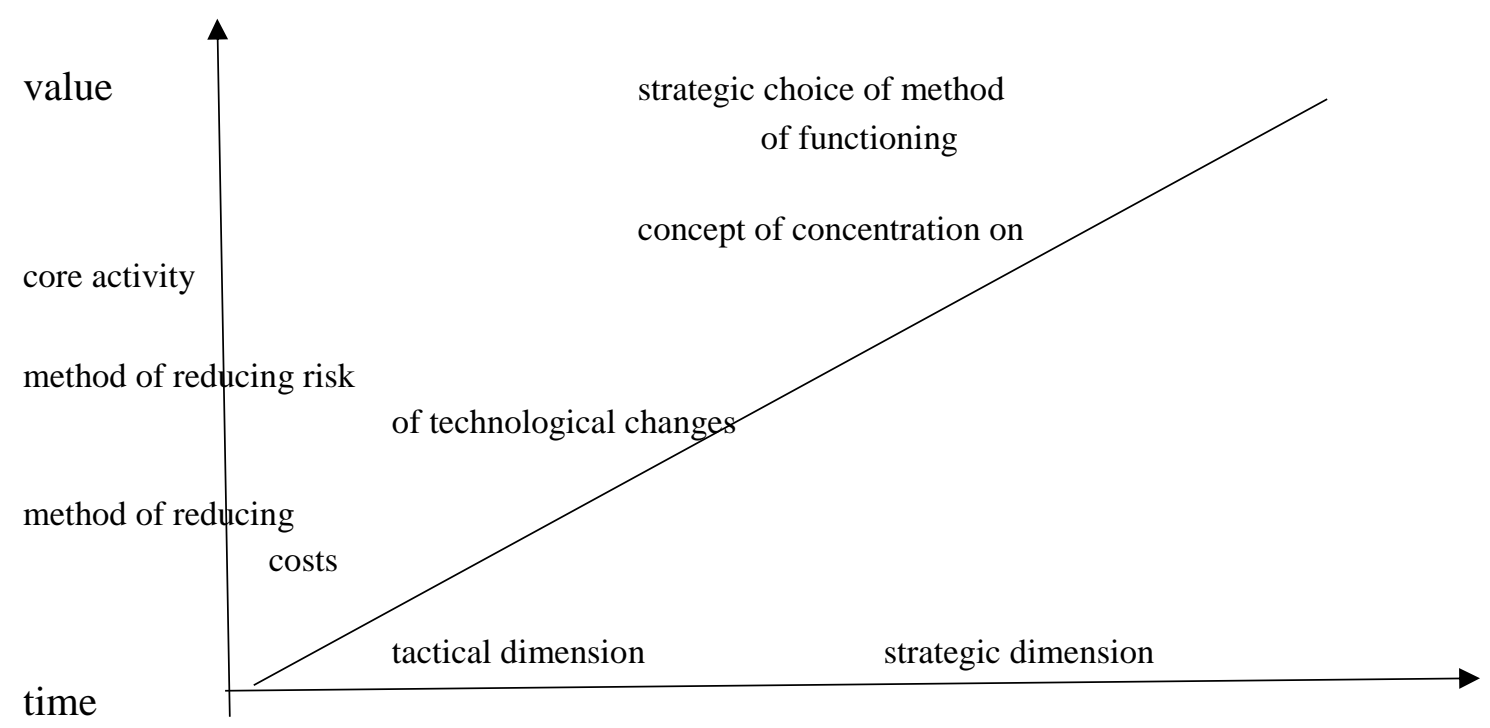

Source: M. Trocki, Outsourcing, PWE, Warsaw 2001, p. 43.

The essence "If there is a thing that we cannot do more efficiently, cheaper or better than a competition, there is no point in doing it further. We should hire the one who does it better than we do".

Outsourcing is defined as the purchasing products or services from the sources outside of the given organization ${ }^{5}$. According to M. F. Corbett, outsourcing consists of hiring external groups to perform the works that the enterprise does not want to, or cannot, perform on its own. According to M. F. Greaver, outsourcing means entrusting external service providers, based on the provisions included in an agreement (contract), with the internal tasks of the organization and the employees, machinery, devices, equipment, technologies and other resources associated with the provision thereof, as well as the associated decision-making competences.

\footnotetext{
${ }^{3}$ Weinert, Stephan, and Kirsten Meyer. "The evolution of IT outsourcing: From its origins to current and future trends." (2005), p. 1.

${ }^{4}$ A.P. Bartel, S. Lach, N. Sicherman, Technological Change and the Make-or-Buy Decision, "Journal of Law, Economics and Organisation", vol. 30, No. 1/2014, pp. 165-192.

${ }^{5}$ Lankford, William M., and Faramarz Parsa. "Outsourcing: a primer." Management Decision (1999), p. 310.
} 
In general terms, outsourcing is a concept of management that reduces the scope of tasks performed inside an enterprise and entrusting an external entity with performing them. It is believed that almost any function may be outsourced. The starting point is differentiating the functions that are of key significance for the enterprise. In those terms, outsourcing leads to a reconstruction of the internal structures of the enterprise. The objective of outsourcing is access to expertise and the possibility to concentrate on core operations, which leads to the improvement of the competitive advantage.

The outsourcing process may be divided into several phases in order to quickly eliminate the potential weaknesses ${ }^{6}$ :

- the concept phase includes:

a) specification of objectives,

b) specification of objectives and costs resulting from outsourcing cooperation,

c) specification of outsourcing-related opportunities and risks,

- the execution phase includes:

a) outsourcing implementation schedule,

b) informing the employees of the planned outsourcing,

c) choosing the potential providers of services,

d) preparing inquiries for quotation,

e) negotiations of the terms and conditions of the agreement,

f) choosing the service provider,

g) outsourcing cooperation schedule,

- the operating phase includes:

a) execution of the first tasks,

b) outsourcing cooperation,

c) control of the use of outsourcing.

\section{Outsourcing Agreement}

Outsourcing agreements are examples of innominate contracts. As an innominate contract, an outsourcing agreement has certain features visible in certain nominate agreements, e.g. contracts of mandate or contract for specific work. As a result, in the case of the absence of provisions to the contrary, the regulations concerning those agreements may apply.

An outsourcing agreement should be drawn up in writing. This protects both parties to the agreement in the case of a dispute concerning the scope thereof or their respective rights and obligations. Signing an agreement should be preceded by negotiations concerning the interests of both parties, as an agreement should guarantee security for both parties and specify in detail their obligations and the risks they incur. For that purpose, it is recommended that outsourcing agreements be negotiated by legal teams ${ }^{7}$. The relationships between outsourcing partners are of long-term character, which allows developing long-term relations.

\footnotetext{
${ }^{6}$ Matejun M., Proces outsourcingu w praktyce gospodarczej małych i średnich przedsiębiorstw (Outsourcing in the economic practice of small and medium enterprises), [in:] Matwiejczuk W. (ed.), Dylematy organizacji gospodarczych. Teoria i praktyka początku XXI wieku (Dilemmas of economic organizations. Theory and practice of early 21st century), Difin, Warsaw 2011, pp. 121-139

${ }^{7}$ Sherwood, John. "Managing security for outsourcing contracts." Computers \& Security 16.7 (1997), p. 603.
} 
The prerequisite is correct communication and a high degree of trust. The objective is gaining mutual benefits from the cooperation.

The elements of an outsourcing agreement may be adapted to a specific relationship with a client. The parties may freely shape the scope of the agreement, but it must contain certain specific elements (see table No. 1).

Table 1 Elements of an outsourcing agreement

\begin{tabular}{|c|c|}
\hline $\begin{array}{l}\text { Elements of an outsourcing } \\
\text { agreement }\end{array}$ & Description \\
\hline $\begin{array}{l}\text { Specification of the parties to } \\
\text { the agreement }\end{array}$ & $\begin{array}{l}\text { The correct specification of the parties to the agreement allows pursuing } \\
\text { potential claims in the future. }\end{array}$ \\
\hline Scope of the Agreement & The agreement should specify all the tasks included in the scope. \\
\hline Rules of Providing the Services & $\begin{array}{l}\text { The agreement should specify the starting date, place of provision, and } \\
\text { scope of the tasks. }\end{array}$ \\
\hline Liability & $\begin{array}{l}\text { The agreement should include the provisions on liability, such as lack of } \\
\text { liability of the outsourcing company in the case of failure by the client to } \\
\text { provide the information. }\end{array}$ \\
\hline Remuneration & $\begin{array}{l}\text { The agreement must specify the remuneration for the service provider and } \\
\text { the remuneration for additional services. }\end{array}$ \\
\hline Duration of the Agreement & $\begin{array}{l}\text { The agreement may be concluded for a definite or indefinite period time. It } \\
\text { should contain provisions on the period of notice and the resulting } \\
\text { settlements between the parties. The duration of an agreement concluded } \\
\text { for a specified period of time should be sufficient for the enterprises to } \\
\text { obtain the long-term benefits of cooperation. The period of cooperation } \\
\text { should be at least two years, although one-year agreements are also } \\
\text { popular in business practice. }\end{array}$ \\
\hline Amendments to the Agreement & $\begin{array}{l}\text { The agreement should specify the terms and conditions of potential } \\
\text { amendments thereto. }\end{array}$ \\
\hline Data Security & $\begin{array}{l}\text { The agreement must specify the procedures concerning the security of the } \\
\text { data provided during the performance thereof. }\end{array}$ \\
\hline Disputes & $\begin{array}{l}\text { An outsourcing agreement should provide for the possibility of disputes } \\
\text { and the provisions on amicable settlement thereof. }\end{array}$ \\
\hline References to other provisions & $\begin{array}{l}\text { In the case of matters not governed by the agreement, there should be } \\
\text { included references to other provisions, in particular to the civil code. }\end{array}$ \\
\hline Contractual Penalties & $\begin{array}{l}\text { The agreement should specify contractual penalties apply if the provider } \\
\text { fails to perform or improperly performs its obligations. }\end{array}$ \\
\hline Proper Court & $\begin{array}{l}\text { The agreement should specify the laws of which country will apply to the } \\
\text { performance thereof. }\end{array}$ \\
\hline Provisions of the Agreement & $\begin{array}{l}\text { The agreement must specify the form and number of counterparts for each } \\
\text { party. }\end{array}$ \\
\hline Signatures & The agreement must be signed by both parties. \\
\hline
\end{tabular}

Source: M. Trocki, Outsourcing, PWE, Warsaw 2001, pp. 126-129, D. Kowal, B. Mazurkiewicz, Umowy wieloletniej kooperacji (outsourcingu) przedsiębiorstw (Agreements on long-lasting cooperation (outsourcing) between companies) [in:] "Ekonomika i Organizacja Przedsiębiorstwa" ("Economics and Organization of Enterprises"), No. 6/2004, pp. 44-47; K. Markowska, Proponowany przebieg współpracy outsourcingowej na przykładzie usług transportu kolejowego ładunków, Organizacja i Zarządzania (Proposed course of outsourcing cooperation with the example of railway cargo transportation services. Organization and Management.), Zeszyty Naukowe Politechniki Śląskiej, Organizacja i Zarządzanie No. 78, 2015, pp. 258. 
An important element of an outsourcing agreement is a description of services. It should be specific to reduce the free interpretation of the behaviors of the other party. Therefore, it should specify the potential sanctions for the improper performance of the agreement. This allows, if required, to obtain compensation or to force the provider to exercise more care when providing services in the future. It should specify the obligations of both parties, including to provide services of the highest quality, promptly and in accordance with law.

The agreement should specify in detail the amount of remuneration for services and the method of settling it. The remuneration may be lump-sum, i.e. a permanent amount for a certain period time of providing services, or in the form of a percentage. A mixed system may also be used. Additionally, such elements as bonuses, discounts, and price renegotiation may be provided for ${ }^{8}$.

Another important issue is agreeing on the procedures for continuing or ceasing further cooperation. For that purpose, the agreement should specify:

- the terms and conditions of extending the agreement with the given supplier,

- the terms and conditions of terminating the outsourcing agreement.

The agreement should be constructed to secure the interests of both parties, including those related to protecting trade secrets. Trade secrets include non-public technical, organizational, or other information that is of value for the enterprise. It should be noted that trade secrets create competitive advantages, so they should be looked after particularly well.

Another important issue is the determination of liability of the parties to the agreement. Although the client would most often like to transfer the entire risk related to the service to the external partner, usually service providers assume the liability in the scope of the service provided. A non-disclosure agreement is a proof that the given enterprise wants to keep its confidential data for itself.

A non-confidentiality agreement should:

- specify the information covered by trade secrets,

- indicate the objectives for which the confidential information may be used,

- describe the activities to be undertaken to preserve the confidentiality of information,

- indicate the contractual penalty for violating the trade secret,

- indicate the duration of the information confidentiality obligation,

- specify the principles of conduct with the confidential information after termination of the agreement.

Apart from the above guidelines, an outsourcing agreement should specify, in detail, the tasks to be performed by the external provider. Apart from that, depending on the area to be separated, an agreement may specify the competencies necessary for the proper fulfilment of the obligations by the service provider.

While establishing cooperation within outsourcing, one should ensure to specify the principles and scope of the agreement in as much detail as possible. The contract should meet the most common needs of the companies planning outsourcing cooperation, i.e.: business processes optimization in an enterprise, reduction in costs of business, access to service provider's technology, access to know-how, or achievement of planned business objectives.

\footnotetext{
${ }^{8}$ M. Matejun, Outsourcing, [in:] K. Szymańska (ed.), Kompendium metod i technik zarzadzania, teoria i ćwiczenia (Compedium of management methods and techniques. Theory and Practical Exercises), Oficyna a Wolters Kluwer business, Warsaw 2015, p. 231.
} 
An outsourcing contract may reflect the assumptions based on which the negotiations were conducted.

The prerequisite for correct cooperation is proper communication between the parties to the contract. It is recommended that partners to an outsourcing contract demonstrate such characteristics as communication skills, experience, and proper knowledge. The most frequent causes of disagreements include misunderstandings and disrupted communication, or provision of incomplete or unreliable information. In order to eliminate those factors, the following communication channels are recommended (see fig. No. 2).

\section{Figure 2. Recommended Channels of Communication}

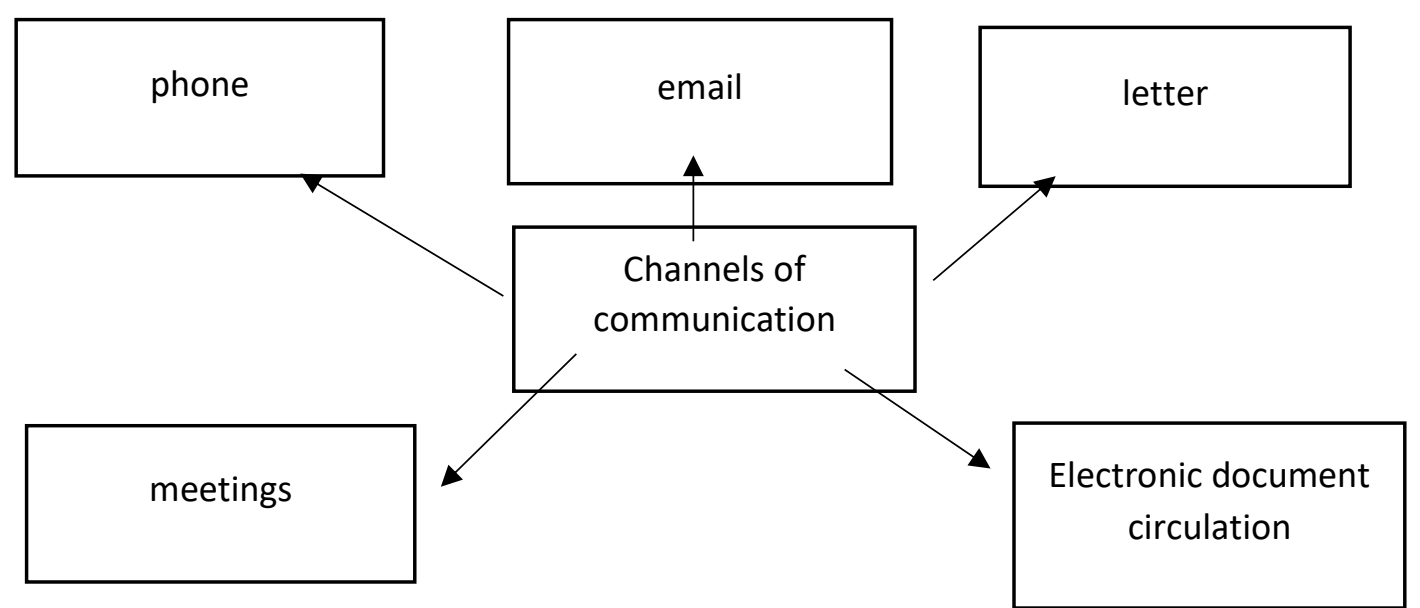

Source: K. Markowska, Proponowany przebieg współpracy outsourcingowej na przykładzie usług transportu kolejowego ładunków, Organizacja i Zarządzania (Proposed course of outsourcing cooperation with the example of railway cargo transportation services. Organization and Management.), vol. 78, 2015, p. 258.

\section{Research Results}

The planned objectives were achieved using the empirical study conducted between 5 and 31 January 2020 among 103 enterprises functioning in the Częstochowa region that outsource tax consulting outsourcing. The study was based on questionnaires. The entrepreneurs could choose multiple answers.

The research sample was dominated by micro-enterprises (0-9 employees) which usually function as sole traders. Small enterprises constituted $4 \%$. The vast majority of respondents operate in the service industry (79\%). 17\% were commercial enterprises, and just $4 \%$ were production companies (see fig. No. 3). All the analyzed enterprises use outsourcing. 


\section{Figure 3. Structure of the Studied Enterprises}

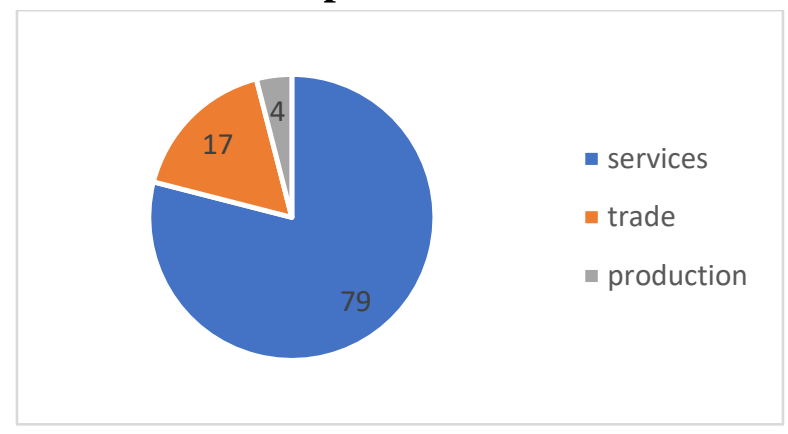

Source: own research.

Based on the research conducted, it occurred that $93 \%$ of the companies have concluded service agreements in writing. Only 7 enterprises admitted they did not have any agreements (see fig. No. 4).

\section{Figure 4. Form of Outsourcing Agreements}

Source: own research.

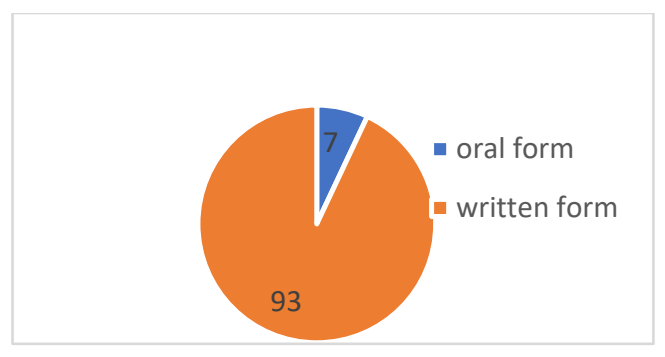

When asked about the criteria adopted by the respondents when choosing the external service provider, the most common responses were: quality of services (83), the scope of services (84) and risk distribution (66). The results confirm the theory that although the price is still important, it is not the decisive factor when choosing the outsourcing partner.

Figure 5. Criteria for choosing the service provider

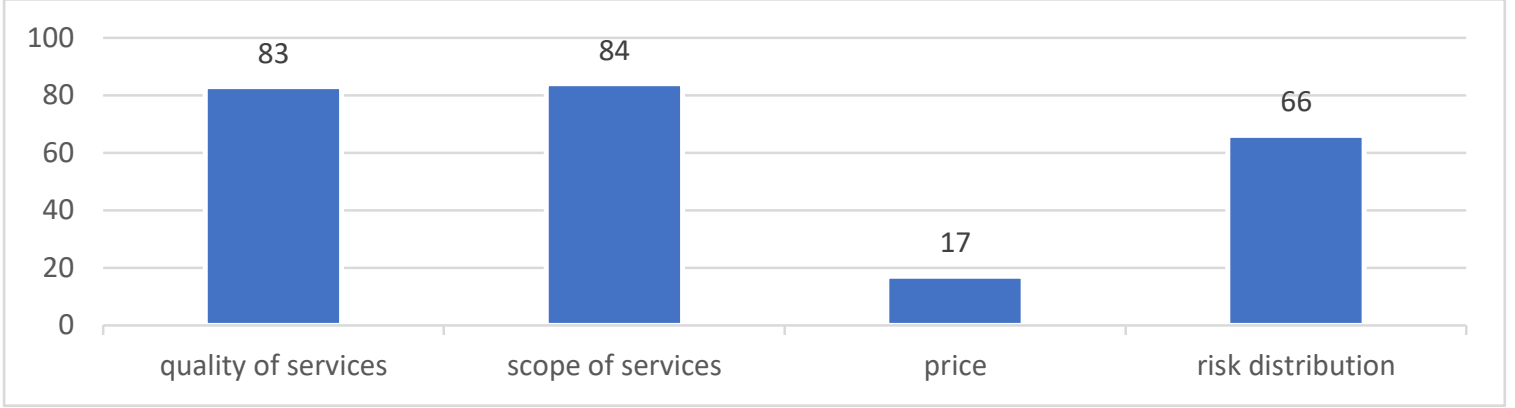

Source: own research.

The answers to the next question were presented in fig. 5. The respondents were asked whether, in their opinion, a properly constructed agreement is decisive for the success of outsourcing. $56 \%$ of them said yes (see fig. No. 6). 
Figure 6. Impart of an Agreement on the Success of Outsourcing

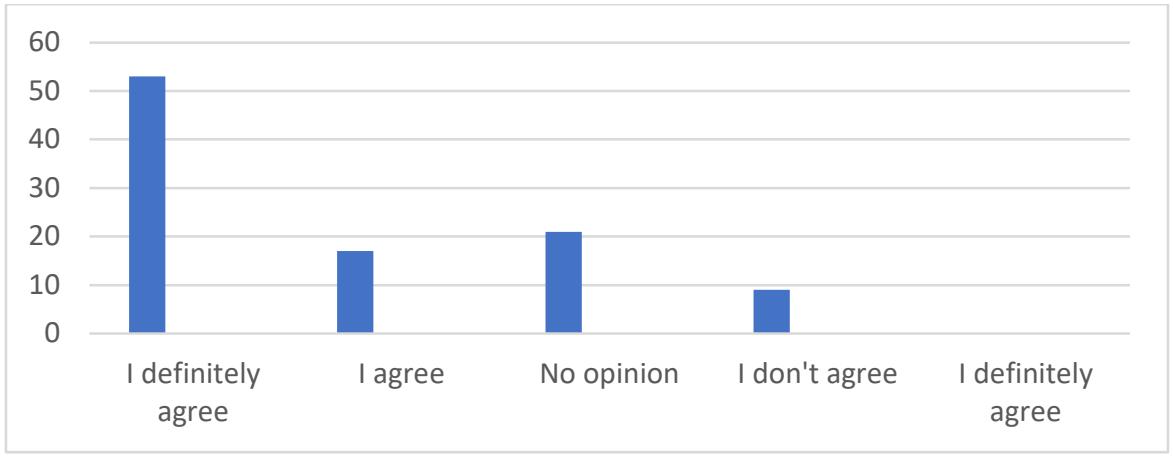

Source: own research.

Then, the period for which agreements are concluded was studied. It occurs that the agreement was concluded for an indefinite period of time in almost all of the studied enterprises. These results confirm the thesis that outsourcing agreements describe long-term contracts among entrepreneurs.

\section{Figure 7. Term of Outsourcing Agreements}

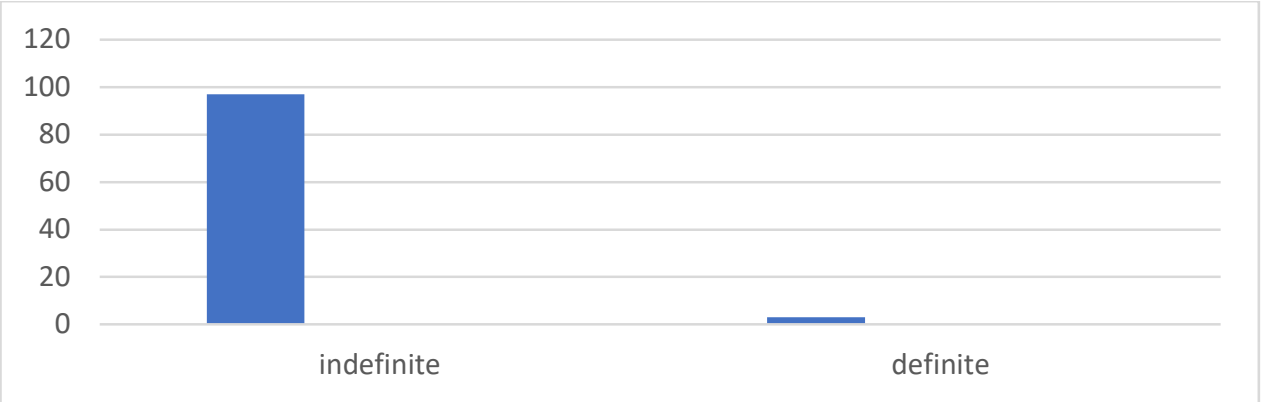

Source: own research.

The answers on the expected benefits of outsourcing cooperation included: cost reduction (90), improvement in the quality of the separated area (78), access to expertise (46) and the possibility to concentrate on core operations (88) (see fig. No. 8)

Figure 8. Benefits of outsourcing

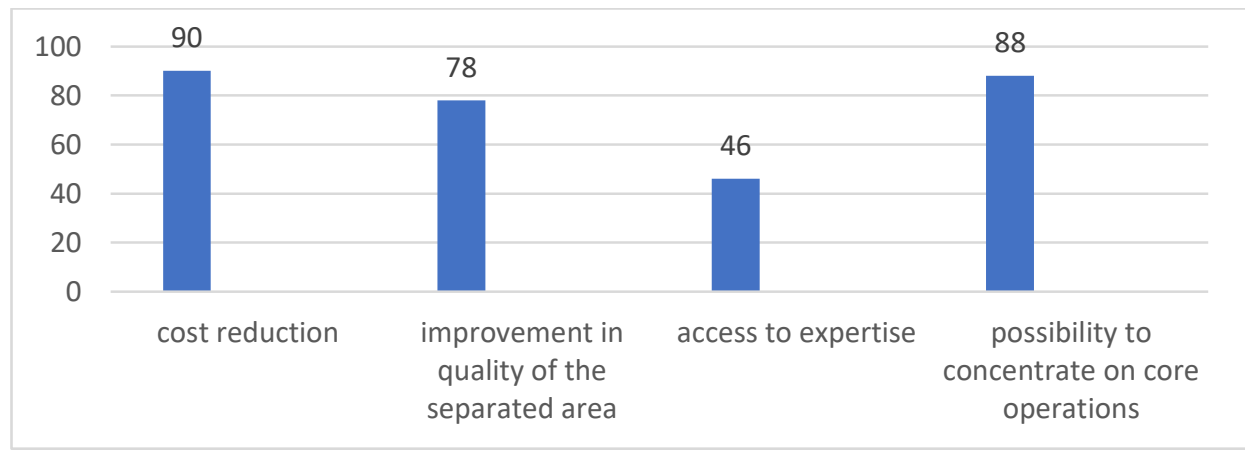

Source: own research. 


\section{Summary}

Although outsourcing is often studied, there are still gaps that deserve scientific interest. The results of that research, both analysis of the literature quoted in this paper and the empirical research in the form of surveys for small enterprises, allowed to arrive at the following conclusions:

- price is not the most important criterion when choosing an outsourcing partner,

- what occurs to be more important is the quality and scope of the services provided,

- the vast majority of outsourcing agreements are concluded in writing and an unspecified period time,

- a properly constructed agreement has a significant impact on the success of cooperation,

- the most important expected benefits include reduced costs, possibility to concentrate on core operations, and improvement in the quality of the separated area.

\section{Literature}

1. Bartel A. P., p. Lach, N. Sicherman, Technological Change , and the Make-or-Buy Decision, "Journal of Law, Economics, and Organisation", vol. 30, No. 1/2014, pp. 165-192.

2. Belcourt, M. (2006). Outsourcing-The benefits and risks. Human resource management review, 16(2), 269.

3. Champy J., M. Hammer, Reengineering the Corporation: a manifesto for business revolution, Harper Business, New York 1993, p. 46.

4. Lankford, William M., and Faramarz Parsa. "Outsourcing: a primer." Management Decision (1999), p. 310.

5. Markowska K., Proponowany przebieg współpracy outsourcingowej na przykładzie usług transportu kolejowego ładunków, Organizacja i Zarządzania (Proposed course of outsourcing cooperation with the example of railway cargo transportation services. Organization and Management.), vol. 78, 2015, p. 258.

6. Matejun M., Outsourcing, [in:] K. Szymańska (ed.), Kompendium metod i technik zarzadzania, teoria i ćwiczenia (Compedium of management methods and techniques. Theory and Practical Exercises), Oficyna a Wolters Kluwer business, Warsaw 2015, p. 231.

7. Matejun M., Proces outsourcingu w praktyce gospodarczej małych i średnich przedsiębiorstw (Outsourcing in the economic practice of small and medium enterprises), [in:] Matwiejczuk W. (ed.), Dylematy organizacji śgospodarczych. Teoria i praktyka początku XXI wieku (Dilemmas of economic organizations. Theory and practice of early 21 st century), Difin, Warsaw 2011, pp. 121-139

8. Weinert, Stephan, and Kirsten Meyer. "The evolution of IT outsourcing: From its origins to current and future trends." (2005), p. 1. 